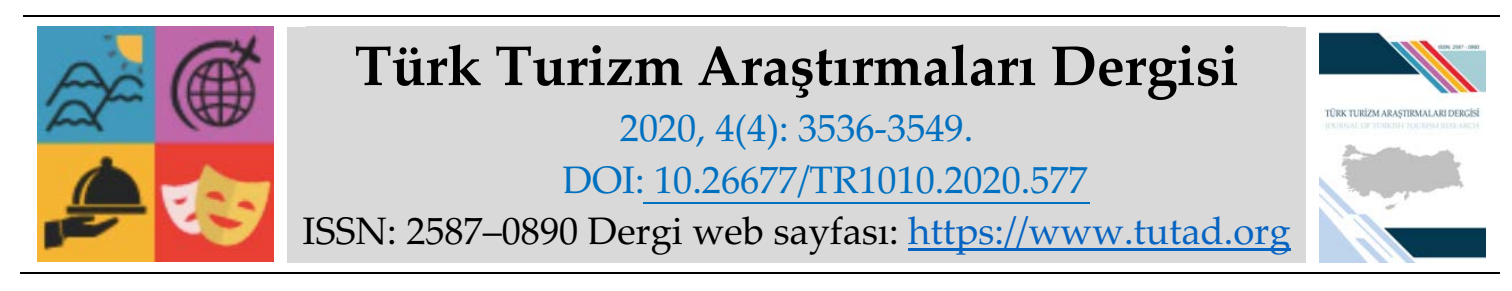

ARASTTIRMA MAKALESI

\title{
Yerli Halkın Perspektifinden Toplum Temelli Turizm: Yazılıkaya-Midas Vadisi Örneği
}

Dr. Öğr. Üyesi Ece DOĞANTAN, Anadolu Üniversitesi, İşletme Fakültesi, Eskişehir, e-posta: edogantan@anadolu.edu.tr ORCID: https://orcid.org/0000-0002-7644-4228

Öz

Toplum temelli turizm, yerel toplulukların ihtiyaçlarını karşılayan, kararlara katılımını önemseyen, kaynaklara erişimini kolaylaştıran ve gelirin yerli halk arasında adil dağılımını sağlamaya çalışan bir turizm çeşididir. Toplum temelli turizm aynı zamanda başta sosyoekonomik olmak üzere sosyo-kültürel ve çevresel açıdan doğrudan ya da dolaylı olarak yerli halkı etkileyebilecek pek çok dinamiği içerir. Bu dinamiklerden yola çıkarak, araştırmada, Yazılıkaya-Midas Vadisinin toplum temelli turizm açısından geliştirilmesinde yerli halkın bakış açısının değerlendirilmesi amaçlanmıştır. Bu amaçla veriler, nitel araştırma yaklaşımlarından yüz yüze görüşme tekniği kullanılarak toplanmıştır. Katılımcılar, kartopu örnekleme yöntemiyle belirlenmiş, elde edilen veriler betimsel analiz yöntemiyle kategorize edilerek yorumlanmıştır. Araştırma sonucunda yerli halkın toplum temelli turizmin gelişimine karşı olumlu bir yaklaşım sergilediği belirlenmiştir. Bölgede yerel girişimciliğin özendirilmemesi, yerli halkın yaşam kalitesinin düşük olması ve bölgenin yerli halkın çıkarlarını gözeten katılımcı yönetim anlayışından yoksun olması ise olumsuz yönleri olarak değerlendirilmiştir.

Anahtar Kelimeler: Toplum Temelli Turizm, Yerli Halk, Yazılıkaya-Midas Vadisi.

Makale Gönderme Tarihi: 01.06.2020

Makale Kabul Tarihi: 07.10.2020

\section{Önerilen Atıf:}

Doğantan, E. (2020). Yerli Halkın Perspektifinden Toplum Temelli Turizm: Yazllıkaya-Midas Vadisi Örneği, Türk Turizm Araştırmaları Dergisi, 4(4): 3536-3549.

(c) 2020 Türk Turizm Araştırmaları Dergisi. 


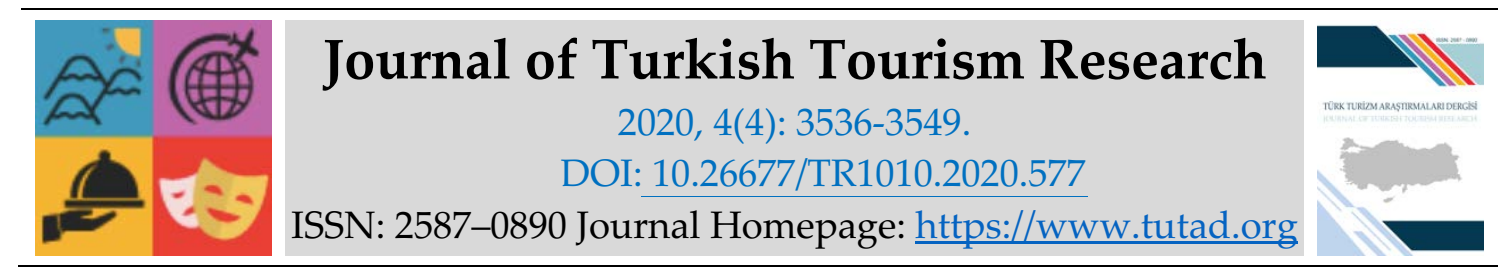

\title{
$\underline{\text { RESEARCH PAPER }}$
}

\section{Community-Based Tourism from Perspectives of Local People: The Case of Yazılıkaya-Midas Valley}

Assistant Prof. Dr. Ece DOĞANTAN, Anadolu University, Faculty of Management, Eskişehir, email: edogantan@anadolu.edu.tr

ORCID: https://orcid.org/0000-0002-7644-4228

\begin{abstract}
Community-based tourism is a type of tourism that meets the needs of local communities, prioritizes locals' participation in decisions, facilitates access to resources, and ensures fair distribution of income amongst locals. Community-based tourism also includes many dynamics that can directly or indirectly affect the local people, especially in terms of socio-economic, sociocultural, and environmental aspects. Based on these dynamics, the aim of the study was to evaluate the local people's perspective on the development of Yazllkaya-Midas Valley in terms of community-based tourism. For this purpose, the research was designed qualitatively, and faceto-face interview technique was utilized. Participants were selected using the snowball sampling method, and the data obtained were categorized and interpreted by the descriptive analysis method. It has been determined that the local people approach positively toward the development of community-based tourism. The fact that local entrepreneurship is not encouraged in the region, the quality of life of the local people is low, and that the region lacks a participatory management approach that looks after the interests of the local people have been identified as negative aspects.
\end{abstract}

Keywords: Community-based Tourism, Local People, Yazılıkaya-Midas Valley.

Received: 01.06.2020

Accepted: 07.10.2020

\section{Suggested Citation:}

Doğantan, E. (2020). Community-Based Tourism from Perspectives of Local People: The Case of Yazılıkaya-Midas Valley, Journal of Turkish Tourism Research, 4(4): 3536-3549.

(C) 2020 Türk Turizm Araştırmaları Dergisi. 


\section{Gíriş}

Turizm endüstrisinin geleceği, yerel toplulukların özellikle hassas kırsal alanlarda turizmi geliştirme ve sürdürme yeteneğine bağlıdır (Fong vd., 2017:147). Kent sakinlerinin sosyoekonomik koşullarının iyileştirilmesi, iş hayatının stresinden uzaklaşma, çevre kirliliği ve gürültüden kaçma isteği, turizmin gelişmesinde büyük önem taşımaktadır (Halbway ve Taylor, 2006:199). Bu arzu neticesinde ortaya çıkan talep kırsal alanların kalkınmasında ve gelişmesinde oldukça önemlidir. Günümüzde birçok ülkenin kırsal alanların kalkınmasında tarım temelli kalkınma stratejilerinin yanı sıra toplum temelli turizm stratejileri uyguladıkları da görülmektedir. Özellikle Türkiye'de Yedinci Beş Yıllık Kalkınma Planı itibariyle politikaların odağının; turizm sektöründe kitle turizminin bir gereği olan yatak kapasitesinin artırılmasından, kırsal turizm, sorumlu turizm, toplum temelli turizm gibi çevreye duyarlı turizm türlerinin geliştirilmesine kaydığı dikkat çekmektedir. Dokuzuncu Kalkınma Planında (2007-2013) turizm sektörünün ülkedeki refah ve gelişmişlik dengesizliklerini azaltıcı doğrultuda yönlendirileceği ve turizm potansiyeli olan destinasyonlarda turizmin geliştirilerek ekonomik ve sosyal kalkınmanın sağlanacağı belirtilmektedir (www. pbk.tbmm.gov.tr).

Uzun yıllar kırsal kalkınma, tarımsal kalkınma olarak anlaşılmış ve yapılan çalışmalar bu alanda yoğunlaşmıştır. Ancak kırsal bölgelerin kalkınmasını sağlayan projeler, kırsal bölgede hayatını sürdüren insanların beklentilerine tam olarak karşılık verememiştir. Bu bakış açısıyla son yıllarda sanayi ve tarım gibi toplum temelli turizm de yerel kültür ve kaynakların korunması ve yönetilmesi açısından özellikle ekonomik boyutuyla kırsal kalkınma aracı olarak görülmektedir (Nelson, 2003:2). Araştırma sahasını oluşturan ve Eskişehir sınırları içinde yer alan YazılıkayaMidas Vadisi, zengin turistik ve kültürel değerlere sahip olmasına rağmen, bir turizm destinasyonu olarak algılanması henüz istenilen düzeyde değildir. Son birkaç yılda Turizm Bakanlığı'nın öncülüğünde bölgenin toplum temelli turizm açısından geliştirilebilmesi amacıyla çeşitli projeler yürütülmektedir. Ancak bölgenin gelişiminin planlı ve sürdürülebilir bir bakış açısıyla ele alınmasında, toplum temelli turizm paydaşlarından biri olan yerli halkın da görüşlerinin alınması önem taşımaktadır. Turizm otoritelerine ve hükümetlerine rehberlik etmek için pek çok çalışmaya ihtiyaç varken, toplum temelli turizmin gelişimini yerel topluluklar açısından inceleyen çok az sayıda çalışmanın olduğu görülmektedir. Bu noktadan hareketle araştırmada, Yazılıkaya-Midas Vadisinin toplum temelli turizm yaklaşımıyla turizme kazandırılmasında otoritelere rehberlik etmesi açısından yerli halkın bakış açısının değerlendirilmesi amaçlanmıştır. Araştırmanın ilk bölümünde yapılan literatür taramasında, toplum temelli turizm kavramı ile yerli halk ilişkisi ele alınmıştır. Daha sonra araştırma alanı olarak belirlenen Yazılıkaya-Midas Vadisinin turizm potansiyeli irdelenmiş ve bölge hakkında yapılan turizm araştırmalarının sonuçlarına yer verilmiştir. Saha araştırmasında ise toplum temelli turizm yaklaşımıyla bölgenin sosyo-ekonomik, sosyo-kültürel ve çevresel göstergelerinin nasıl olduğu ve nasıl bir gelişim göstereceği yerli halkın bakış açısıyla yansıtılmaya çalışılmıştır.

\section{KAVRAMSAL ÇERÇEVE}

\section{Toplum Temelli Turizm}

Toplum temelli turizm, yerli halkın katılımını önemseyen, onların kendi topraklarında meydana gelen ve kendi bölgelerinde bulunan, doğal ve kültürel çekiciliklere dayanan turizm çeşidi olarak tanımlanmakta ve özellikle kırsal destinasyonlar için bir kalkınma aracı olarak görülmektedir (Nelson, 2003:2). Ekonomik açıdan ele alındığında toplum temelli turizm; yerli halkın yaşam tarzından, doğal kaynaklarından ve kültürlerinden gelen ürünleri turistlere sunarak ekonomik 
fayda elde etme ve yerel ekonomiyi geliştirme temeline dayanmaktadır (Lee ve Jan, 2019:368369). Sosyolojik açıdan değerlendirildiğinde, gelişmiş ve gelişmekte olan ülkeleri, kentsel ve kırsal toplulukları, farklı coğrafyadan insanları bir araya getiren toplum temelli turizmin, sosyal yapıyı etkilediği belirtilmektedir. Toplum temelli turizmde önemli görülen yerli halkın katılımı, toplumun doğal çevresini ve kültürünü turizm ürünleri olarak korumak için katalizör görevi üstlenirken, aynı zamanda turizmle ilgili daha fazla geliri teşvik etmektedir (Doğantan, 2020). Çevresel açıdan değerlendirildiğinde ise toplum temelli turizm genellikle doğal ve kültürel kaynaklar açısından zengin ancak olumsuz faktörlere karşı kırılgan bir çevrede yaşayan topluluklar için sürdürülebilir bir geçim kaynağı sunmaktadır. Literatür incelendiğinde toplum temelli turizmin özellikleri şu şekilde özetlenebilir: Toplum temelli turizm:

- Sürdürülebilir turizmin ayrılmaz bir parçasıdır (Okazaki, 2008:511),

- Yerli halkı planlama, karar verme, yönetim, uygulama ve kontrol sürecine dâhil eder (López-Guzmán vd., 2011:1610),

- Kadınlar ve gençler gibi toplumun dezavantajlı kesimlerinin ekonomik, sosyal ve politik olarak güçlendirilmesine yardımcı olur (Karacaoğlu vd., 2016:118),

- Sürdürülebilirlik, katılımcılık, güçlendirme ve özgüveni birleştirir (Goodwin ve Santilli, 2009).

- Yerel destinasyona ve topluluğa sağladığı çeşitli faydalar nedeniyle farklı uluslararası örgütler tarafından da desteklenir (Karacaoğlu vd., 2016:104),

- Yerel ekonomik faydaları dengede tutarken doğal çevre ile kültürü korumayı, topluluğun yaşam kalitesini artırmayı ve turistler için yüksek kaliteli bir deneyim sağlamayı amaçlar (Choi ve Sırakaya, 2006:1275).

Literatür incelendiğinde toplum temelli turizm ile sürdürülebilir turizm, eko-turizm, kırsal turizm ve sorumlu turizm kavramlarının birbirine çok benzer olduğu, kimi zaman bu kavramların birbirlerinin yerine kullanıldığ 1 dikkat çekmektedir. Aslında, temelinde sürdürülebilirlik yaklaşımlarını barındırdı ğı için toplum temelli turizm, sürdürülebilir turizmin ayrılmaz bir parçası olarak düşünülebilir. Kırsal turizm, kırsal toplulukların temel bir parçası olan etkinliklere katılıp buradaki çekicilikleri deneyimlemek için kırsal destinasyonlara yapılan seyahatleri temsil eder ve toplum temelli turizmin de genellikle kırsal destinasyonlarda geliştirilmeye çalışılmaktadır. Sorumlu turizm, 'sorumlu olmak' kavramı ile birçok turizm çeşidine ve paydaşlarına uygulanabilirdir ve bu yönüyle toplum temelli turizm de sorumlu davranışı gerektirmektedir. Toplum temelli turizm, aynı zamanda toplum temelli eko-turizm olarak tanımlanmaktadır. Bu yönüyle eko-turizmin sosyal boyutunu bir adam daha ileri götürür ve toplum temelli eko-turizm özellikle yerli halkın gelişimi ve yönetimi üzerinde önemli bir kontrole sahip olduğu ve faydalarının büyük bir kısmının topluluk içinde kaldığı bir eko-turizm çeşidi olarak görülür (Varumo, 2016:1).

Kırsal destinasyonlarda turizm gibi alternatif turizm türlerinin geliştirilmesi özellikle turizm destinasyonu olmaya aday bölgelerin ve bu bölgelerde yaşayan yerli halkın güçlendirilmesi açısından önemli görülmektedir (Yurdakul, 2019:110). Ayrıca toplum temelli turizmde konaklama hizmetleri genellikle köylü veya çiftçinin bizzat kendi evinde, kırsal pansiyonlar veya otellerde, kırsal tatil köyleri ve kamping alanlarında verilmektedir. Bu durum ise toplum temelli turizm açısından yerli halkı önemli bir paydaş konumuna taşımaktadır.

\section{Toplum Temelli Turizm ve Yerli Halk}

Toplum temelli turizmin sosyo-ekonomik, sosyo-kültürel ve çevresel boyutlarıyla yerli halkı doğrudan ya da dolaylı olarak etkileme potansiyeli vardır. Sosyo-ekonomik açıdan değerlendirildiğinde, öncelikle toplum temelli turizm, yerli halkın yaşam tarzından, doğal kaynaklarından ve kültürlerinden gelen ürünleri turistlere sunarak ekonomik fayda elde etme ve 
yerel ekonomiyi geliştirme temeline dayanmaktadır (Lee ve Jan, 2019:368-369). Bununla birlikte turizmin bölgesel kalkınmaya katkıda bulunabilmesi için yerli halkın aktif olarak turizm faaliyetlerine katılması ve yerli halkın işlettiği küçük işletmelerin desteklenmesi gerekmektedir (Roney, 2011). Dolayısıyla toplum temelli turizmin en önemli sosyo-ekonomik etkisi, yerli halkı ekonomik olarak güçlendirmesidir. Ekonomik açıdan güçlendirmenin göstergelerinden bazıları; ekonomik bağlantıların geliştirilmesi, ortak girişimler, yerli halkın katılımı ve yerel üretimdir. Yerli halkı da içine alan toplum temelli turizm projelerinin, kırsal ekonominin tarım, gıda gibi diğer sektörleriyle bütünleştirilmesiyle karşılıklı destekleyici bağlantılar oluşturulabilmekte böylece sızıntılar önlenebilmektedir. Ayrıca yerli gruplar ve özel turizm işletmeleri arasında gerçekleştirilen ortak girişimler, yerli halk için gelir sağlamaktadır. Toplum temelli turizmde, yerel girişimciliğin özendirilmesi, hem yerli halkı ekonomik olarak güçlendirmekte hem de yerli halkın katılımını sağlayarak turizmin ekonomik faydalarına ilişkin karar verme süreçlerini sahiplenmesini mümkün kılmaktadır (Doğantan, 2020).

Turizm; gelişmekte olduğu bölgede gelir, istihdam, enflasyon vb. ekonomik unsurların yanı sıra örf ve âdet, gelenek ve görenek, yaşam tarzı gibi kültürel birtakım değişimleri de beraberinde getiren hareketler bütünüdür. Bu nedenle özellikle kırsal destinasyonlarda turizm hareketlerinin halkın isteği olmadan geliştirilmeye çalışılması halkın anti pati, nefret, düşmanca davranışlar geliştirmesine yol açabilir. Yerli halkın turizm faaliyetlerinin gelişimini istemesi ve desteklemesi planlamanın başarısına katkı sağlarken, bir bölgede yerli halkın turizmi istememesi o bölgede turizm faaliyetlerinin gelişmesini engelleyecek önemli bir konudur (Yeşiltaş, 2013:28). Buna karşlık toplum temelli turizm, yerli halkın katılımı ile mümkündür ve tüm planların toplumun genel sosyo-ekonomik gelişimi ile bağlantılı olması gerekir. Bu nedenle özellikle kırsal destinasyonlar toplum temelli turizm anlayışıyla geliştirilirken sadece ekonomik ve çevresel boyutunun değil sosyo-kültürel boyutlarının da dikkate alınması gerekmektedir.

Doğal kaynaklar, yerli halkın ziyaretçilere sunduğu turizm ürünlerinin önemli bir parçasını oluşturduğu için toplum temelli turizmle çevre arasında çok yakın bir ilişki vardır. Öncelikle toplum temelli turizm, yerli halk ile turistlerin doğal ve kültürel kaynaklara sahip çıkarak korunmalarını teşvik eder. Ayrıca tüm paydaşlar, çevresel anlamda turizmin gelişmesinin getireceği olumsuz etkilerin farkındadır ve bu etkileri hafifletmek için gerekli tedbiri alırlar. Toplum temelli eko-turizm yaklaşımından hareket eden topluluklar; yerli halk için daha sürdürülebilir bir geçim kaynağı sağlar. Yerli halkın çevreyi koruma konusunda daha fazla katılımını teşvik eder, yerli halkı güçlendirir ve korunan alanlar gibi biyolojik çeşitliliğin zengin olduğu bölgeleri gelecek nesillere aktarma konusunda olumlu bir yaklaşımı teşvik eder (Doğantan, 2020).

Araştırmalarda turizm destinasyonlarının yerel, bölgesel hatta küresel boyutta her türlü olumsuz çevresel koşuldan etkilenmeye çok açık olduğu ve dolayısıyla kırılgan bir yapıda olduğu vurgulanmaktadır (Yılmaz, 2004; Doğantan ve Kozak, 2019:128). Bölgede toplum temelli turizmin geliştirilmesinin yerel toplulukların geleneklerine ve geçim kaynaklarına zarar vermesi durumunda oluşabilecek olumsuz etkilerden belki de en önemlisi, bu değişimin yaratacağ baskı ve yerli halkın değişime karşı direncidir. Bu etkilerin yanı sıra toplum temelli projelerin bazı destinasyonlarda yoksulluğu ve yerli halkın kırılganlığını nadiren azalttığı; bu nedenle yerli halk için kırılgan ve sürdürülebilir olmayan bir geçim kaynağı sunduğu da belirtilmektedir (Zapata vd., 2011:745). Toplum temelli turizm projesinin Bursa Misi Köy'de yarattığı fayda ve maliyetlerin yerli halk arasında nasıl paylaşıldığının ortaya konulması amacıyla gerçekleştirilen bir araştırmada, topluluktaki herkesin turizm gelişiminden fayda sağlamadığı, fayda sağlayanların ise projeye daha olumlu yaklaştıkları belirlenmiştir (Karacaoğlu vd., 2016:103). Ancak olumsuzluklara rağmen yerli halkın turizmin planlanması ve yönetimine dâhil edilmesi diğer bir ifadeyle katılımcılık anlayışıyla değişime uyum sağlamalarının büyük ölçüde 
sağlanabileceği belirtilmektedir (López-Guzmán vd., 2011:1610). Örneğin, Botswana'da toplum temelli turizmin yerli halk için başta güçlendirme olmak üzere, doğal kaynakların korunması üzerine de olumlu etkilerinin olduğu belirlenmiştir. Araştırmada toplum temelli girişimlerin, doğru bir şekilde yürütülür ve yönetilirse, doğal kaynakların korunmasını teşvik edebileceği ve turizm faaliyetlerine katılarak yerel faydaları artırabileceği öne sürülmektedir (Sebele, 2010:136).

\section{Yazılıkaya-Midas Vadisi ve Turizm}

Tarih öncesi çağlardan günümüze kadar çok sayıda uygarlığa ev sahipliği yapan Frig Vadisi (Phryg Valley), turizm çekicilikleri açısından oldukça zengin bir bölgedir. Bölgede Kültür ve Turizm Bakanlığı tarafından korunan ve Türkiye Kültür Mirası listesinde yer alan pek çok sit ve tescilli yapı bulunmaktadır (Aşılığlu ve Memlük, 2010:186). T.C. Eskişehir Valiliği (2010) tarafından belirlenen kültürel turizm çekicilikleri arasında Midas Anıtı, Bitmemiş Anıt, Areyastis Anıtı, İnli Kaya, Gerdekkaya Mezarı, Hamamkaya Frig Kaya Mezarı, Ayterek Kale, Deveboynu Kalesi, Doğanlı Kale, Karanlık Dere, Yapıldak Asar Kale, Dübecik Kale, Akpara Kale, Gökgöz Kale, Pişmiş Kale, Kocabaş Kale bulunmaktadır.

Araştırma alanı olarak belirlenen Yazılıkaya-Midas Vadisi, Dağlık Frigya Bölgesi sınırları içerisinde yer alır (Polat, 2008:10). Günümüz Eskişehir İli'nin yaklaşık olarak 70 km güneyinde, Han ve Seyitgazi İlçeleri sınırlarında kalan Yazılıkaya-Midas Vadisi, pek çok kültüre ve uygarlığa ev sahipliği yapmıştır (Polat, 2018:263). Bu uygarlıklardan biri de Friglerdir. Frigler, M.Ö. 1200'lerde deniz kavimleri göçü sonunda Makedonya ve Trakya'dan Kuzey İç Batı Anadolu' ya geldikleri düşünülen topluluktur. Friglerin en tanınmış siyasi kimliği Kral Midas, Helen mitolojilerine konu olmuştur. Friglerin en önemli merkezleri Gordion (başkent), YazılıkayaMidas kenti ve Hattuşaş'taki Frige kentidir. Yerleşimleri düz alanlarda olduğu halde, dağlık kesimde sarp tepelere kurulmuş kaleleri vardır (Alanyalı, 2019:32). Bölge, Frig Uygarlığına ait yerleşimlerin ve kaya anıtlarının en anıtsal ve tekil örneklerini barındırması nedeniyle, özellikle kültürel miras turizmi açısından önemli bir destinasyondur. Ayrıca bölge, doğa temelli alternatif turizm türleri bakımından da önemli bir potansiyele sahiptir. Vadinin büyük oranda volkanik yapısı nedeniyle kayalar zamanla deformasyona uğrayarak Nevşehir'de bulunan peri bacalarına benzer bir görünüm oluşturmaktadır. Ancak, bölge turizm açısından önemli çekicilik merkezlerinden biri olarak görülse de tanitımının henüz yeterli düzeyde olmadığ belirtilmektedir (Kozak ve Yılmaz, 2010:96; Doğantan, 2014:40; Seyhan, 2014:96). Kültür ve Turizm Bakanlığı'nın toplam ziyaretçi sayılarına ilişkin tuttuğu istatistikler (Tablo 1.) ve yapılan araştırmalar da bu durumu desteklemektedir. Örneğin, Eskişehir'e gelen 387 yerli turistin kentin kültür turizmi potansiyelinden yararlanma düzeyleri araştırıldığında "Eskişehir Size Neyi Çağrıştırıyor?" sorusuna karşılık yalnızca \%3'ünün (13 kişi) Yazılıkaya ve Frig Vadisi olarak yanıt verdiği belirlenmiştir (Üsküdar vd., 2014:69).

Tablo 1. Kültür ve Turizm Bakanlığı Midas (Yazılıkaya) Örenyeri Toplam Ziyaretçi İstatistikleri (2016-2018)

\begin{tabular}{|l|l|l|}
\hline Yıl & Örenyeri & Ziyaretçi Sayısı \\
\hline 2018 & Midas (Yazılıkaya) Örenyeri & 7.672 \\
\hline 2017 & Midas (Yazılıkaya) Örenyeri & 1.493 \\
\hline 2016 & Midas (Yazılıkaya) Örenyeri & 9.070 \\
\hline
\end{tabular}

Kaynak: www.dosim.gov.tr 
Literatür incelendiğinde bölgenin sahip olduğu doğal ve kültürel özelliklerin, bir turistik çekicilik unsuru olarak tanıtılması amacıyla yerel yönetimler ve üniversiteler gibi paydaşlar tarafından çeşitli çalışmaların yapıldığı görülmektedir. Bu kuruluşlardan biri 2009 yılında Bakanlar Kurulu kararıyla Afyonkarahisar, Eskişehir ve Kütahya il özel idareleri tarafından kurulan Frigya Kültürel Mirasını Koruma ve Kalkınma Birliği'dir (FRİGKÜM). Bu birlik Frig Vadisi projesi ile bölgenin canlandırılması ve korunması için çalışmalar yapmaktadır. Proje kapsamında 2013 yılında gerçekleştirilen Frig Yolu ile 506 km'den oluşan 3 ana rota ve rotalar üzerinde konaklama alanları belirlenmiştir. Bölgenin doğal, tarihi, jeolojik, kültürel vb. bileşenlerini içerecek şekilde tasarlanan Frig Yolu, doğa tutkunu gezginleri, Friglerin 3000 yıl önce yürüdükleri bu güzergâhları, bir Frigyalı gibi günümüzde yürümelerini sağlamaktadır. Ayrıca Frig Yolu güzergâhı üstündeki bazı köylerde köy evleri restore edilerek ev pansiyonculuğuna uygun hale getirilmiştir (www.frigvadisi.gov.tr). Anadolu Üniversitesi Arkeoloji Bölümü, Eskişehir Eti Arkeoloji Müzesi ve İst. Rest. Kons. Mer. ve Böl. Lab. Müdürlüğü ortak projesi olarak 2017 yılında hayata geçirilen Yazılıkaya Midas Vadisi Araştırması ve Koruma Planlaması çalışmaları kapsamında yapılan araştırmalardan biri de ziyaretçiler için gezi rotalarının belirlenmesidir. Uzun ve kısa turlardan oluşan bu rotalar, ziyaretçilere Yazılıkaya'da bulunan 16 farklı kültürel mirası görme fırsatı sınmaktadır (www.midaskent.com).

Bölgede yürüyüş rotalarının belirlenmesinin yanı sıra doğa temelli turizmin en önemli formlarından biri olan kamping potansiyelinin belirlenmesine yönelik de bazı çalışmalar yürütüldüğü görülmektedir. Frig Vadisi potansiyel kamp alanları, yürüyüş ve bisiklet rotalarının Coğrafi Bilgi Sistemleri (CBS) aracilığıyla belirlendiği bir araştırmada çok kriterli karar verme yöntemleri kullanılmıştır. Yapılan uygunluk analizleri sonucu ortaya çıkan harita yorumlandığında, Vadide kamp alanına en uygun bölge 1208 km² olarak tespit edilmiş, en uygun kamp alanı kriteri de diğer kriterlere eklenerek Vadide uygun rotalar belirlenmiştir (Bektöre vd., 2018:35). Dağlık Frigya Bölgesinde alternatif konaklama olarak karavancıllı̆ı̆ önerildiği farklı bir araştırmada Yazılıkaya-Midas Vadisine yakın kırsal bazı bölgelerin karavancılık için uygun olup olmadığı yerli halk, karavancılar ve yerel yönetimlerin bakış açısıyla değerlendirilmiştir. Bu kapsamda öncelikle Delfi yöntemi ile potansiyel bir karavan alanının sahip olması gereken kriterler belirlenmiş, daha sonra bu kriterler kapsamında gözlem, görüşme ve ikincil veriler aracılığıyla Frig Vadisi için değerlendirmeler yapılmıştır. Araştırma sonuçları değerlendirildiğinde Frig Vadisinde yer alan her iki bölgenin karavan alanı (kamping) olarak yatırımcılara açılabileceği görülmüştür. Araştırmada karavan veya kamping tesisinin işletilmesinde rekreatif kolaylıklar olarak da nitelendirilen üst yapı yatırımları konusunda yerel yönetimlere ve yatırımcılara öneriler sunulmuştur (Doğantan, 2014:117).

Yerel yönetimler ve Anadolu Üniversitesi'nin işbirliğinde gerçekleştirilen projelerden biri de turizm alanındadır. Firg Vadisinde bulunan Seyitgazi'nin Sakin Şehir (Slow City/Cittaslow) hareketine uygunluğunun tespitine yönelik yapılan projede, Seyitgazi'yi doğaya saygıll, tarihi yapıyı koruyan, tarımsal üretimi zengin, yerel tatlara sahip, kültür turizmine odaklı, bilinçli bir kent kültürüne dönüştürmek amaçlanmıştır. Projede öncelikle, Seyitgazi'nin uluslararası sakin şehir standartları kapsamında değerlendirilmesi yapılmıştır. Araştırmanın sonucunda, Seyitgazi ilçesinin Sakin Şehir standartlarına uyabilmeleri için çevre, altyapı, tesisler, yerel üretimi koruma, misafirperverlik ve farkındalık konularında yerel yönetime öneriler sunulmuştur (Kozak ve Aksöz, 2013). Yörede başarılı bir kültürel miras turizmine ulaşılıp ulaşılamayacağı, kültürel mirasın korunması ve ziyaretçilerle bütünleşmede izlenecek yolların neler olduğunun belirlenmesi amacıyla gerçekleştirilen çalışmalardan biri Seyhan (2014) tarafından yapılmıştır. Yönetimlerin, yerli halkın ve ziyaretçilerin görüşlerine dayanarak, Frigya'nın kültürel miras turizmi potansiyelinin yüksek olduğu, ancak bölgeye gereken önemin verilmediği, tanıtımla ilgili etkili çalışmaların yapılmadığı belirlenmiştir. Ayrıca araştırma sonucunda bölgede konaklama 
olanakları, engelliler için uygunluk, ulaşım, yeme-içme, bilgilendirme, döviz bürosu ve ATM gibi altyapı olanaklarının yeterli düzeyde olmadığı belirlenmiştir. Dağlık Frigya Bölgesi ve Kral Yolu üzerinde alternatif turizm türleri kapsamında bir model önerisi geliştirmeyi amaçlayan farklı bir çalışmada, paydaşlarla yapılan görüşmeler sonucunda katılımcılar; Dağlık Frigya Bölgesi içerisinde koruma-bakım çalışmaları, çevre temizliği, denetleme, sürdürülebilirlik, yenileme ve restorasyon faaliyetlerinin yeterli miktarda yürütülmediği görüşünü benimsemişlerdir. Bölgede bulunan define avcılarının faaliyetlerinin hala sonlandırılmaması, altyapı ve üstyapı çalışmalarının yürütülmemesi, çevre temizliğinin yetersiz yapılması, tarihi eserlere verilen zararların giderilememesi, trafik tabela ve işaretçilerinin yetersiz olması ve yerli halkın çıkarlarının tam anlamıyla korunmaması paydaşların bölgenin geleceğiyle ilgili kaygı ve endişelerini arttırmaktadır (Yurdakul, 2019:111).

\section{YÖNTEM}

Araştırma sosyal bir olguyu derinlemesine anlamlandırmak ve irdelemek ihtiyacından hareketle nitel bir araştırma olarak desenlenmiştir. Nitel araştırmalar, araştırmacının rolü üzerine kurularak, verilerin toplanması, çözümlenmesi ve yorumlanması sürecini içermektedir (Creswell, 1994:143-144). Çalışmada, yorumlayıcı bir yaklaşımla incelemeyi benimseyen nitel veri toplama araçlarından yüz yüze görüşme tekniği kullanılmıştır.

Araştırmanın evrenini, Yazılıkaya Köyünde 10 hanede yaşayan 43 kişi oluşturmaktadır. Örneklemin belirlenmesinde kartopu örnekleme yönteminden yararlanılmış, evrenden herhangi birine ulaşıldıktan sonra ondan alınan isimle toplam 10 katılımcıya ulaşılmıştır. Örneklemin Yazılıkaya Köyü'nde söz sahibi (kanaat önderleri) kişilerden seçilmesine özen gösterilmiştir. Veri toplama sürecinde ilgili literatürden yararlanılarak oluşturulan yarı yapılandırılmış görüşme sorularından yararlanılmıştır. Bu kapsamda yöre halkının aşağıdaki sorulara yanıt vermeleri beklenmiştir.

- Sizce Yazılıkaya-Midas Vadisinde yapılabilecek turizm aktiviteleri nelerdir?

- Bölgenin turizme açılmasının getireceği sosyo-kültürel etkiler nelerdir?

- Bölgenin turizme açılmasının getireceği çevresel etkiler nelerdir?

- Bölgenin turizme açılmasının getireceği ekonomik etkiler nelerdir?

- Bölgedeki turizm faaliyetlerini destekler misiniz? Desteklemek için neler yapardınız?

- Bölgede turizmin gelişmesi için önerileriniz nelerdir?

Görüşmeler kayıt altına alınmıştır. Nitel araştırmalarda yapılan görüşmelerde elde edilen veriler yeterli düzeye geldiğinde katılımcı sayısını fazlalaştırmaya ihtiyaç duyulmamaktadır (Miles ve Huberman, 1994). Bu kapsamda bilgilerin tekrar etmeye başlaması nedeniyle yeterli olduğu kanaatine varılan verilerin analiz kısmında analitik betimleme süreci temel alınmıştır. Bu evre, belirli bir ifadenin/mesajın taşıdığı veya içerdiği enformasyonun işlenmesini esas almaktadır. Yöntemin ilk adımı betimsel işlemedir. Burada elde edilen kavramlardan veya ifadelerden belirli kayıt birimleri (kodlanacak anlamlı birimler) oluşturulur. Bu kayıt birimleri içerik analizinde en küçük analiz birimleri olarak adlandırılan kodlardır (Kumtepe vd., 2019:49).

Belirtilen sorular temelinde bir ön kodlama şeması geliştirilmiş ve 'turizm çekicilikleri', 'çevresel etkiler', 'ekonomik etkiler', 'sosyo-kültürel etkiler' olmak üzere 4 farklı tema belirlenmiştir. Kayıt altına alınan görüşme ve tartışma verileri önceden belirlenen bu temalar ışığında betimsel olarak analiz edilmiş, bu süreçte doğrudan alıntılara yer verilmiştir. Betimsel analiz sürecinde incelenen içerikte kodların neler olduğu ve bunların hangi temalar altında toplandığ incelenmiştir. İlişkisel analizde ise belirlenen kodlar arası ilişkiler incelenmiş ve benzerlik ve farklılıklar kod ve temalar üzerinden değerlendirilmiştir. 


\section{BULGULAR}

Yazılıkaya Köyünde yaşayan ve araştırmanın örneklemini oluşturan katılımcıların demografik özellikleri aşağıda açıklanmaktadır (Tablo 2).

Tablo 2. Katılımcların Demografik Özellikleri

\begin{tabular}{|l|l|l|l|}
\hline Cinsiyet & Yaş & Eğitim & Çalışma Durumu \\
\hline Erkek & 30 & Üniversite & Çalışıyor \\
\hline Erkek & 52 & İlkokul & Emekli \\
\hline Erkek & 45 & İlkokul & Çalışıyor \\
\hline Erkek & 62 & İlkokul & Emekli \\
\hline Erkek & 56 & Lise & Emekli \\
\hline Erkek & 48 & Lise & Çalışıyor \\
\hline Erkek & 44 & Lise & Çalışıyor \\
\hline Kadın & 47 & İlkokul & Çalışıyor \\
\hline Kadın & 42 & İlkokul & Ev hanımı \\
\hline Kadın & 38 & İlkokul & Ev hanımı \\
\hline
\end{tabular}

Katılımcıların çoğunun erkek, 30 yaşının üzerinde, ilkokul mezunu ve Yazılıkaya Köyünde ikamet ettiği belirlenmiştir.

\section{Turizm Çekicilikleri ve Rekreatif Unsurlar}

Katılımcıların tümü bölgede yapılacak turizm aktivitelerinin en önemlisinin kültür turizmi olduğunu belirtmiş, birkaç katılımcı kamp ve karavan turizminin bölgede yapılabileceğini belirtirken, çoğunun alternatif turizm türleri ve aktiviteleri hakkında bilgi sahibi olmadığ 1 gözlenmiştir. Özellikle bölgenin kış aylarında çetin hava koşullarına sahip olması, toprağın kıraç ve parçalı yapısı, yerleşimin plansız gelişmesi nedeniyle turizm açısından yer sıkıntısı olabileceği belirtilmiştir. Bazı katılımcılar ise köyün ilerisinde mesire alanı, çeşme, gölet, ardıç ormanı vb. turizm çekiciliklerinin oluğu, bu nedenle kültür turizmine alternatif olarak farklı turizm türlerinin de geliştirilebileceğini belirtmişlerdir.

Turistik ürünün en önemli bileşenlerinden biri de turizm işletmeleridir. Katılımciların görüşlerine göre Yazılıkaya-Midas Vadisinde restoran ve butik otel olmak üzere yalnızca iki turistik işletme bulunmaktadır. Yazılıkaya Köyünde bulunan ve bölge halkı tarafından işletilen restoran, turist rehberleriyle yapılan işbirliğine dayalı olarak turların olduğu dönemlerde turist gruplarına hizmet vermektedir. Çukurca Köyünde bulunan Midas Butik Otel ise yabancı turist, bürokrat ve bilim insanları gibi üst gelir grubuna hitap etmektedir. Midas Anıtına çok yakın 
mesafede bulunan, eskiden düğün ve şenliklerin yapıldığı köy binası ise restore edilerek, gelen günübirlik ziyaretçilerin kullanıma sunulmuştur.

\section{Ekonomik}

Yazılıkaya Köyü 1. ve 3. derece arkeolojik sit alanı içinde yer almaktadır. Sit alanı koruma ve kullanma koşullarına göre 1. derece arkeolojik sit alanlarının korumaya yönelik bilimsel kazılar dışında aynen korunacak sit alanları olarak belirlenmesi, köyün ekonomik olarak kalkınmasına sekte vurmaktadır. Bu kapsamda bölgede yaklaşık 10 hanede binaların yenilenmesine izin verilmemektedir.

'Geçen gün Gaziantep'ten geldiler. Ziyaretçilerden biri açlıktan ölüyorum diye söyleniyor. Evin kenarına bir market açma imkânımız yok... Hizmet veremiyoruz.'

'Köye dönmek isteyenler var ancak dört duvar var. Çatı bile yapamıyoruz. Neden gelsinler.'

'Amerika'dan bir arkadaşımız geldi buraya, yer alıp pansiyon yapacaktı, izin alamadı.'

Yazılıkaya'da ekonomik gelişmenin olmaması, köy halkının kente göçünü hızlandırmış ve bölgede üretim yapacak genç nüfusun sayısı azalmıştır. Bu durum yalnızca ekonomik anlamda turizmin gelişimini etkilememiş aynı zamanda bölge halkını, temel ihtiyaçlarını karşılaması açısından dışa bağımlı hale getirmiştir.

'Her şeyi hazır alıyoruz. Ekmek bize iki günde bir geliyor. Haftada iki kere bakkal geliyor. Seyyarlar çürükleri satıyor, mecbur alıyoruz.'

Katılımclara göre tanıtım ve pazarlama faaliyetlerinin yetersizliği, bölgeye olan turistik talebin düşmesine neden olmaktadır. Eskişehir'deki birkaç seyahat acentasının çabalarıyla yürütülen tur organizasyonları yılın belli dönemlerinde yoğunluk kazansa da turistik talebin dalgalı olması yerel girişimcilerin yatırım kararlarını etkilemektedir.

'Bölgeye bütçe ayrılmadığı için broşür bile basılmıyor, bölgeye gelen turist sayısı azalıyor. Sürekli gelen olmayınca da çalışanın sigortası, işletmenin vergisi ağır geliyor haliyle...'

'Seyahat Acentasl, tur kapsamında ziyaretçilere daha çok Eskişehir merkezde zaman harcatıyor. Burada turist bir saat kalıyor. Bölgede konaklayacağı tesis olsa belki anlaşabilir.'

\section{Çevresel}

Bölgenin dağınık bir yerleşim düzenine sahip olması ve sit alanı olması nedeniyle yenileme çalışmalarının yapılamaması çevresel açıdan görüntü kirliliğine neden olmaktadır. Ayrıca kente göç nedeniyle genç nüfusun az olması, çevrenin ihmal edilmesine neden olmuştur. Güvenlik açısından değerlendirildiğinde; bugüne kadar hırsızlık, sözlü saldırı gibi jandarma ve polisin olaya müdahale etmesine neden olabilecek sorunların olmaması, bölgenin güvenli olduğu izlenimini yaratmaktadır. Güvenliğin yanı sıra gürültü de turizm alanlarında önemli çevresel unsurlardan biri olarak ele alınmaktadır. Yerli halk bölgenin çok sessiz olduğunu, birkaç münferit ziyaretçi dışında herhangi bir gürültü sorunu yaşamadıklarını belirtmişlerdir.

'Çocuklar geldiğinde bazen gürültü yapıyorlar ancak köyümüz genelde sessiz olduğu için gürültü̈yü seviyoruz. Mağarada ses yankı yaptı̆̆ı için zaman zaman bağıtranlar oluyor, keyif alıyorlar.'

Buna karşıllk bazı ziyaretçilerin bahçelere izinsiz girmesi ve eşyaların kullanımı konusunda fütursuz davranışları yerli halkı rahatsız etse de bu tür olayların pek sık yaşanmadığını 
belirtmişlerdir. Bölgede yerli halkın aktif olarak yaşamını sürdürmesinin, yaşanabilecek güvenlik sorunlarının önlenmesinde önemli bir etkisi olduğu belirtilmektedir.

'Aşağıda kral mezarları var. Sik sık define avcıları tarafından patlatılıyor. Burada hiçbir olay olmadı şimdiye kadar.'

\section{Sosyo-Kültürel}

Yazılıkaya Köyünde yaşayanlar Karaçay Çerkez Türkleridir. Çerkez kültürünün yansıması olarak insanlarla sıcak ilişkileri olduğunu belirten yerli halk, bölgede turizmin gelişmesine sıcak baktıklarını ve gelişimi için ekonomik, sosyal ve çevresel her türlü desteği verebileceklerini belirtmişlerdir.

'Gelen turistlerin örf ve adetlerine saygı duyuyoruz, gelen yabancı turistleri evimizde çok yatırdık, yemek yedirdik.'

Geçen gün inek sağıyorum. Bir ziyaretçi abla yoğurt var mı sende çok acıktım dedi. Süt verdim, para vermek istedi, almadım. İzmir'den amcam aradı, senin fotoğrafını dergide gördük diye. Meğer o turist gazeteciymiş, bizim misafirperverliğimizi övgüyle anlatmış.'

Misafirliğin yanı sıra gürültü ve kirlilik konusunda da turistlere karşı toleranslı olan yerli halk, ekonomik olarak beklentileri olmadan ziyaretçileri zaman zaman evlerinde ağırladıklarını belirtmişlerdir.

\section{SONUÇ ve ÖNERILLER}

Kalkınma aracı olarak toplum temelli turizm faaliyetlerinin bir destinasyonda planlanması ve uygulanabilmesi için bölge halkının turizme karşı tutumlarının araştırılması önem taşımaktadır. Bu kapsamda gerçekleştirilen araştırmada, Dağlık Frigya'da bulunan Eskişehir'deki YazılıkayaMidas Vadisinin toplum temelli turizm yaklaşımıla bir turizm destinasyonu olarak turizme kazandırılmasında yerli halkın bakış açılarının değerlendirilmesi amaçlanmıştır. Araştırma sonucunda yerli halkın toplum temelli turizmin gelişimine karşı olumlu yaklaştıkları ve alternatif turizm türlerinden doğa, kültür ve kamp ve karavan turizmi kapsamında destinasyonun geliştirilebileceği konusunda hem fikir oldukları belirlenmiştir. Yerli halkın gözlemlerine göre bölgeyi en çok ziyaret eden turist profilini kampçlar, izciler ve günübirlik ziyaretçiler oluşturmaktadır. Bu nedenle bölgede kamp ve karavan turizminin geliştirilerek; çadır, karavan, bungalow gibi konaklama alternatiflerini sunan kampinglerin hizmet vermesi, turizmin canlandırılması açısından önemlidir. Bunun yanı sıra toplum temelli turizmin sık uygulanan projelerinden biri olan aile yanında konaklama programlarının (homestay) bölgede uygulanmasıyla turistler, yerli halkın çiftçilik gibi günlük, festivaller, ritüeller gibi kültürel etkinliklerini, bölgenin doğal çekiciliklerini ve trekking, yürüyüş gibi açık alan aktivitelerini gözlemleme ya da bizzat katılma fırsatına sahip olabilirler (Boonratana, 2010). Ayrıca bu programlar sayesinde hem ekonomik olarak hem de eğitim ve öğretimle yerli halk güçlendirilmekte böylece aktif olarak katılımları da sağlanmaktadır. Turizmin gelişmesinin çevresel açıdan herhangi bir negatif etki yaratmayacağını düşünen yerli halkın, bölgede turizmin geliştirilmesi konusunda her türlü ekonomik ve sosyal desteği vermeye hazır olduklarını belirtmeleri, topluluk projelerini destekleyeceklerinin de bir göstergesidir.

Bölgede turizmin gelişimine sekte vurabilecek en önemli husus yerel girişimciliğin yok denecek kadar az olmasıdır. Buna karşlık toplum temelli turizmde yerel kaynakların etkin yönetimi ve turizm faydalarının daha iyi dağıtılması için yerli halkın turizm altyapı, hizmet ve tesislerinin 
işletilmesi konusundaki faaliyetlere katılımı önemlidir. Dolayısıyla yerli halkın kendi kaynaklarının ve topraklarının kontrolü ve kullanımı yoluyla kendi girişimlerini yürütmelerine yardımcı olmak için yerel girişimciliğin desteklenmesi gerekmektedir. Araştırma sonuçları ise yerli halkın girişimcilik konusunda istekli olduklarını ancak teşvik ve eğitim gibi destek sistemleri hakkında yeterli bilgiye sahip olmadıklarını göstermektedir. Bu kapsamda yerel yönetimler, sivil toplum örgütleri, vakıflar, dernekler gibi yapıların turizme destek vermeleri ve girişimcilerin ihtiyaçlarına duyarlılık göstermelerinin önemli olduğu düşünülmektedir. Özellikle yerel yönetimlerin festivaller, konserler gibi bölgeye insanları çekebilecek çeşitli etkinlikleri düzenlemeleri, turizm girişimcilerine yönelik ekonomik teşvik ve destek sağlamaları girişimciliğe yönelik olumlu bir iklim yaratmada etkili olacağı belirtilmektedir (Cakir ve Doğantan, 2019:344).

Yazılıkaya' da toprağın verimsiz olması üretim faaliyetlerini kısıtlayarak kente göçü tetiklemesine rağmen yakın mesafede Midas Anıtı gibi önemli kültürel miras alanları ile doğal peyzaj unsurlarının olması, bölgenin turizme kazandırılması konusunda avantaj yaratmaktadır. Ancak bölgedeki turizmi destekleyici iklime rağmen, turizmin gelişimine sekte vurabilecek bazı hususlar yerli halk tarafından belirtilmektedir. Bu hususlardan belki de en önemlisi sit alanı içinde yaşayan yerli halkın evlerinde herhangi bir yenileme yapamamalarıdır. Bu durum yerli halkın yaşam kalitesini etkilemekle birlikte yaşadıkları yere aidiyet duygusunu azaltarak göç sorununu gündeme getirmektedir. Buna karşılık bölge halkının kültürel peyzaj alanlarına yakın mesafede yaşamaları arkeolojik eserlerin güvenliğini sağlamada olumlu etki yaratmaktadır. Dolayısıyla yerli halkın ihtiyaçlarını, katılımcı yaklaşımları, kaynaklara erişimi, adil dağılımı ve ekonomik çeşitliliği ön plana çıkaran daha bütüncül bir bakış açısıyla, bölgede tüm turizm paydaşlarının ortak akıl ile hareket ettikleri bir destinasyon yönetim örgütü kurulmasının destinasyonun toplum temelli turizm açısından gelişime büyük katkı yapacağı düşünülmektedir. Ayrıca başarıyı değerlendirmek ve kırılganlıkları belirli ölçüde önleyebilmek için toplum temelli turizm projeleri, düzenli izleme ve geri bildirim yoluyla önemli ölçüde güçlendirilebilmektedir. $\mathrm{Bu}$ kapsamda ekonomik performans, yerli halkın algısı ve refahı, ziyaretçi memnuniyeti ve çevresel etki değerlendirmelerinin yapılması ve yerli halkın bu konularda bilgilendirilmesi de önerilmektedir.

\section{KAYNAKÇA}

Alanyalı, H. S. (2019). İlk Çağlar, İlk Kültürler, (Editör) Gülmez, B.: Kültür Tarihi içinde (ss. 22-43) Eskişehir: Anadolu Üniversitesi.

Aşılıoğlu, F. ve Memlük, Y. (2010). Frig Vadisi Kültür Mirası Alanlarının Belirlenmesi ve Değerlendirilmesi, Ankara Üniversitesi Çevrebilimleri Dergisi, 2(2): 185-197.

Bektöre, E., Korkmaz, E., Erşen, G. ve Atak, A. (2018). Frig Vadisi Potansiyel Kamp Alanları ve Rotalarının CBS Aracılığıyla Belirlenmesi, GSI Journal. Serie C: Advancements in Information Sciences and Technologies, 1(1): 35-50.

Boonratana, R. (2010). Community-based Tourism in Thailand: The Need and Justification for an Operational Definition, The Kasetsart Journal: Social Science, 31(2): 280-289.

Cakir, O. and Dogantan, E. (2019). Local Tourism Entrepreneurship and Entrepreneurial Climate: The Case of İğneada, Kırklareli, (Editör) Akinci, A.: Interdisciplinary Public Finance, Business and Economics Studies Volume II içinde (ss. 339-346) Berlin: Peter Lang.

Choi, H. C. and Sirakaya, E. (2006). Sustainability Indicators for Managing Community Tourism, Tourism Management, 27(6): 1274-1289. 
Creswell, J. W. (1994). Research Design Qualitative and Quantitative Approaches. United States of America: Sage Publications.

Doğantan, E. (2014). Frigya Bölgesine Alternatif Konaklama Tesisi Önerisi: Karavancllk, Yayınlanmamış Yüksek Lisans Tezi, Anadolu Üniversitesi, Eskişehir.

Doğantan, E. (2020). Toplum Temelli Turizmin Etkileri ve Yerli Halk, (Editörler) Kozak, N ve Toker., A: Toplum Temelli Turizm içinde Eskişehir: Anadolu Üniversitesi.

Doğantan, E. and Akoğlan K. M. (2019). Resilience Capacity in Different Types of Tourism Businesses, Turizam: Međunarodni Znanstveno-Stručni Časopis, 67(2): 126-146.

Fong, S. F., Lo, M. C., Songan, P. and Nair, V. (2017). Self-efficacy and Sustainable Rural Tourism Development: Local Communities' Perspectives from Kuching, Sarawak, Asia Pacific Journal of Tourism Research, 22(2): 147-159.

Goodwin, H. and Santilli, R. (2009). Community-based Tourism: A Success, ICRT Occasional Paper, 11(1): 1-37.

Halbway, C. J. and Taylor, N. (2006). The Business of Tourism. (Seventh Edition), England: Prentice Hall.

http://frigvadisi.gov.tr/index.php/frig-vadisi-2/frig-yuruyus-yolu/ [Erişim Tarihi: 05.06.2020]

http://www.dosim.gov.tr/muze-istatistikleri [Erişim Tarihi: 05.06.2020]

http://www.midaskent.com/sayfalar.asp?sayfa=7 [Erişim Tarihi: 05.06.2020]

https://pbk.tbmm.gov.tr/dokumanlar/kalkinma-plani-9-genel-kurul.pdf [Erişim Tarihi: 05.06.2020]

Karacaoğlu, S., Yolal, M. ve Birdir, K. (2016). Toplum Temelli Turizm Projelerinde Katılım ve Paylaşım: Misi Köyü Örneği, Çağ Üniversitesi Sosyal Bilimler Dergisi, 13(2): 103-124.

Kozak, M. A. ve Aksöz, E. O. (2013). Eskişehir Ili Seyitgazi İlçe Merkezinin Sakin Şehir (Cittaslow) Hareketi Kapsamında Değerlendirilmesi, Yayınlanmamış Bilimsel Araştırma Projesi, BAP No: 1105E103, Anadolu Üniversitesi, Eskişehir.

Kozak, M. A. ve Yılmaz G. E. (2010). Otel Yöneticilerinin İç Girişimcilik Algılamaları: Frigya Bölgesi Örneği, Anatolia: Turizm Araştırmaları Dergisi, 21(1): 85-97.

Kumtepe, G. E., Toprak, E., Öztürk, A., Büyükköse, T. G., Kılınç, H. ve Menderis, İ. A. (2019). Açık ve Uzaktan Öğrenmede Destek Hizmetleri: Yerelden Küresele Bir Model Önerisi, Açıkögretim Uygulamaları ve Araştırmaları Dergisi (AUAd), 5(3): 41-80.

Lee, T. H. and Jan, F. H. (2019). Can Community-based Tourism Contribute to Sustainable Development? Evidence from Residents' Perceptions of the Sustainability, Tourism Management, 70: 368-380.

López-Guzmán, T., Borges, O. and Cerezo, J. M. (2011). Community-based Tourism and Local Socio-Economic Development: A Case Study in Cape Verde, African Journal of Business Management, 5(5): 1608.

Miles, M. B. and Huberman, A. M. (1994). Qualitative Data Analysis: An Expanded Sourcebook. United Kingdom: Sage.

Nelson, F. (2003). Community-based Tourism in Northern Tanzania: Increasing Opportunities, Escalating Conflicts and an Uncertain Future. [Online] https://www.tnrf.org/files/ETNRF_OCCASIONAL_PAPER_No_2_0.pdf [Erişim Tarihi: 27.06.2020]. 
Okazaki, E. (2008). A Community-based Tourism Model: Its Conception and Use, Journal of Sustainable Tourism, 16(5): 511-529.

Polat, R. T. (2018). Yazılıkaya/Midas Vadisi Akpara Kale Mezarları, Olba, 26: 261-284.

Polat, Y. (2008). M.Ö. IV. Binyıl- I. Binyıl Arasında Dağlık Phrygia Bölgesi'nde Yerleşim Modelleri, Yayınlanmamış Yüksek Lisans Tezi, Anadolu Üniversitesi, Eskişehir.

Roney, S. A. (2011). Turizm: Bir Sistemin Analizi. Ankara: Detay Yayıncllk.

Sebele, L. S. (2010). Community-based Tourism Ventures, Benefits and Challenges: Khama Rhino Sanctuary Trust, Central District, Botswana, Tourism Management, 31(1): 136-146.

Seyhan, B. (2014). Frigya Bölgesinin Kültürel Miras Turizmi Kapsamında Değerlendirilmesi, Yayınlanmamış Yüksek Lisans Tezi, Anadolu Üniversitesi, Eskişehir.

T.C. Eskişehir Valiliği (2010). Eskişehir. Eskişehir: T.C. Eskişehir Valiliği Yayınları.

Üsküdar, Ş., Çakır, M. ve Temizkan, S. P. (2014). Yerli Turistlerin Eskişehir'in Kültür Turizmine İlişkin Algıları, Journal of Tourism and Gastronomy Studies, 2(2):67-76.

Varumo, L. (2016). Community-Based Tourism as the Interface of Indigenous and Non-Indigenous Worlds, Unpublished Master's Dissertation, University of Tampere School of Management, Finland.

Yeşiltaş, M. (2013). Destinasyon Geliştirme ve Planlama, (Editör) Yeşiltaş, M.: Destinasyon Yönetimi içinde (ss.18-39) Eskişehir: Anadolu Üniversitesi.

Yılmaz, Ö. D. (2004). Turizm İşletmelerinde Kriz Yönetimi ve Konaklama İşletmeleri Yöneticilerinin Krizlere Yönelik Yaklaşımlarına İlişkin Bir Araştırma, Yayınlanmamış Yüksek Lisans Tezi, Dokuz Eylül Üniversitesi, İzmir.

Yurdakul, A. (2019). Tarihi Ticaret Rotalarmın Alternatif Turizm Faaliyetleri Kapsamında Turistik Değerlere Dönüştürülmesi: Kral Yolu-Frig Vadisine Yönelik Bir Öneri, Yayınlanmamış Yüksek Lisans Tezi, Afyon Kocatepe Üniversitesi, Afyon.

Zapata, M. J., Hall, C. M., Lindo, P. and Vanderschaeghe, M. (2011). Can Community-based Tourism Contribute to Development and Poverty Alleviation? Lessons from Nicaragua, Current Issues in Tourism, 14(8): 725-749. 